\title{
editorial
}

\section{Of the people...}

These are interesting times. The US government is ready to wage war on Iraq-or has already done so, by the time this editorial is published-despite the fact that most Americans did not initially feel threatened by Saddam Hussein. Tony Blair, the British Prime Minister, is disregarding opinion polls showing that more than $80 \%$ of Britons are against a war, and is continuing to send British troops to the Gulf. He, and his colleagues in seven other European countriesPortugal, Spain, Italy, Denmark, Poland, Hungary and the Czech Republicpublished an open letter to US President George W. Bush, in which they expressed their support for a war against Iraq. Most of them did not bother asking their voters, their parliaments or, in the case of former Czech President Vaclav Havel, even their cabinet members first. These countries are genuine democracies, and all share the recent painful experience of other forms of government - with the exception of the UK. But their leaders' support of the USA's war plans shows a complete and utter disregard for the views of the vast majority of their citizens. And this is happening in many areas, not just in whether or not we should go to war. The German Chancellor, Gerhard Schröder, continues to ignore his citizens' demands for reforms to help the country's ailing economy. Prime Minister Silvio Berlusconi of Italy is about to change the country's constitution to give him more power. Tony Blair was elected on the strength of promises to reform, among others, Britain's healthcare and traffic problems, but these seem to be all but forgotten now.

What has this to do with science? Quite a lot, because science depends on the political environment and flourishes only if it is properly nourished by politicians. Cabinets decide how much money from the budget should be allocated to research, and they decide what areas of science should be supported. Politicians also influence the education system from which science recruits its new practitioners and, last, but not least, they have a large input when it comes to salaries and jobs. And, as American scientists are about to learn, politicians can even decide, in the name of national security, what research can be published, which is contrary to one of science's basic principles: the free flow of and access to knowledge.

Democracy is a funny thing, isn't it? It is the government "of the people, by the people, for the people" as US President Abraham Lincoln put it. But in reality, every now and then we are asked to cast our votes and elect politicians into positions of power, only to realize later that these elected representatives rarely act in our interest. Clearly, democracy has its weaknesses, but as Winston Churchill said, "democracy is the worst form of government, except all the others that have been tried from time to time." In fact, when measured according to economic growth, scientific advances or the flourishing of the arts, it is obviously the best form of government compared with all the others. Nevertheless, the need to please the majority of voters to ensure re-election means that sometimes minorities have only a slight chance of being heard. And if they are heard, it is only because they have shouted the loudest in the political arena and raised the most heckles.

Scientists' grievances are obviously not being heard in this shouting match. In the USA, if a scientist happens to come from the wrong country-a decision made by the US administration-they are not allowed to work in areas that are considered sensitive for national security, which again is decided by politicians. Science funding in Europe is increasingly tied to predicted outcomes or economically beneficial research. Germany's education system needs urgent reform as the PISA study has shown that its quality is far worse than even its critics feared. Everywhere in Europe, lack of career opportunities and miserable salaries force young scientists to flock to the USA. The number of students in the natural sciences is dropping in most developed countries because schools increasingly fail to raise interest in the natural sciences in their students, and because the career options for young scientists look rather bleak compared with other professions. At the same time, politicians continue to emphasize the importance of science for future jobs and economic development, and rarely miss a photo opportunity with well-known and influential scientists. Obviously, there is a large gap between their rhetoric and their actions and it is unlikely that this will change soon.

So, what can scientists do to make sure that they are fairly represented? Wallow in self-pity and sink into dark cynicism? Abstain from voting or vote for the most extreme parties, in protest against the establishment? People have their own ways of making their grievances heard. In London, up to two million citizens protested against Blair's war plans; three million demonstrated in Rome; and hundreds of thousands took to the streets of New York and San Francisco. In Germany, opposition to Schröder's sluggishness on reforms draws people onto the street, as do Berlusconi's attempts to change the constitution in Italy. But nobody ever hears scientists openly protesting. This is not a call for mass demonstrations and open rebellion against politicians. But if democracy is increasingly a shouting match where only the loudest are heard in the 'marketplace of ideas', it is probably time that scientists raised their voice. So, perhaps scientists, particularly the younger ones, should learn from the peace movement, disgruntled workers, upset patients and others, and organize themselves. This could be in the form of direct lobbying of members of parliament or government officials, or in the form of public outreach and other types of campaign. Greenpeace and other nongovernmental organizations have shown that, with public support, it is possible to change things. No matter how it is done, the scientific community should make their voice heard, otherwise they will remain ignored. Which would be a real pity, because they have a good case to make.

\section{Holger Breithaupt}

doi:10.1038/sj.embor.embor818 